\title{
The Effect of Treatments Administered to Hospitalized Patients Before the Development of Hospital-Related Hyponatremia
}

\author{
(1) Zeynep Ece Demirbaş, ${ }^{1}$ (1) Gülizar Şahin, ${ }^{2}$ 이 Kadir Kayataş, ${ }^{3}$ (1) Mehmet Tepe, ${ }^{3}$ \\ (1) Yasemin Özgür, ${ }^{4}$ (1) Seher Tanrıkulu, ${ }^{5}$ (b) Refik Demirtunç ${ }^{3}$
}

'Department of Internal Medicine Dr. Siyami Ersek Thoracic and Cardiovascular Surgery Training and Research Hospital, İstanbul, Turkey ${ }^{2}$ Department of Nephrology, Sultan Abdulhamid Han Training and Research Hospital, İstanbul, Turkey ${ }^{3}$ Department of Internal Medicine, Haydarpaşa Numune Training and Research Hospital, İstanbul, Turkey ${ }^{4}$ Department of Internal Medicine, Kartal Dr. Lütfi Kırdar Training and Research Hospital, İstanbul, Turkey ${ }^{5}$ Department of Endocrinology, Haydarpaşa Numune Training and Research Hospital, İstanbul, Turkey

Submitted: 30.07.2018 Accepted: 31.07.2018

Correspondence: Zeynep Ece Demirbaș

Dr. Siyami Ersek Göğüs Kalp ve Damar Cerrahisi Eğitim ve Araştırma Hastanesi, İç Hastalıkları Kliniği, İstanbul, Turkey

E-mail: zeynepece@gmail.com

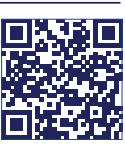

Keywords: Hospital-related hyponatremia; length of hospital stay; medical treatments; mortality; surgery.

\section{ABSTRACT}

Objective: Hospital-related hyponatremia has a significant mortality, and it is widely seen among hospitalized patients. The aim of the present study was to identify the treatments of patients before developing hyponatremia and the relationship between these treatments and severity of hyponatremia, length of hospital stay, and mortality rate.

Methods: The present study was conducted retrospectively on 133 patients who developed hyponatremia during their hospitalization for any reason in our hospital between 2012 and 2013. Demographic features of the patients, sodium values after hyponatremia, treatments applied to the patients before developing hyponatremia, length of hospital stay, and mortality rates were analyzed.

Results: Diuretics composed the largest part (46.6\%) of medical treatments related to hyponatremia before the development of hyponatremia. When any of the treatments that may cause hyponatremia (hypotonic fluids, mannitol, diuretics, other drugs, and surgery) was administered in addition to the current treatment, each factor appeared to prolong the length of hospital stay by $8.1 \pm 1.853$ days.

Conclusion: Although a significant relationship between treatments and mortality rates or hyponatremia severity could not be identified, prolongation in the length of hospital stay was crucial for avoiding complications of hospitalization and also for decreasing the costs of healthcare. This research may also serve as a guide for further prospective case-controlled studies.

\section{INTRODUCTION}

Hyponatremia, which is observed in approximately $30 \%$ of hospitalized patients, ${ }^{[l]}$ plays a significant role in followups of inpatients because it is the most encountered electrolyte imbalance in clinical practice ${ }^{[2]}$ and also according to various studies, it has a mortality rate of $9 \%-51 \%{ }^{[3]}$

Medical treatments, most of all hypotonic fluids and diuretics, which are frequently used among hospitalized patients, and also surgical procedures cause hyponatremia through various mechanisms. ${ }^{[4,5]}$ There are many studies about the effect of hypotonic fluids on the development of hospital-related hyponatremia especially in the pediatric population. ${ }^{[6-10]}$ Diuretics contribute to hyponatremia through sodium $(\mathrm{Na})$ loss via urine or by directly releasing vasopressin or increasing the sensitivity for vasopressin in the collector tubules. ${ }^{\left[{ }^{\prime \prime}\right]}$ Other drugs, such as anticonvulsants, serotonin re-uptake inhibitors, and renin-angiotensin receptor blockers, and also surgical procedures generally cause hyponatremia throughout the syndrome of inadequate antidiuretic hormone (ADH).$^{[12]}$ In hyperosmolar hyponatremia, which may occur after mannitol ad- 
ministration, the increase in serum osmolality draws water out of the cell and decreases $\mathrm{Na}$ concentration by dilution. ${ }^{[13]}$ Analyzing the consequences of these treatments, which are generally used in clinical practice or even administered in combination during hospitalization, is crucial for understanding hospital-related hyponatremia.

The aim of the present study was to identify the treatments of patients before developing hyponatremia and the relationship between these treatments and severity of hyponatremia, length of hospital stay, and mortality rate.

\section{MATERIAL AND METHODS}

The study was conducted retrospectively on 133 patients who developed hyponatremia during their hospitalization for any reason in our hospital between 2012 and 2013. Data of adult patients who met the inclusion criteria were obtained from the records of the hospital. Patients (a) who have hyponatremia at the moment of hospitalization, (b) who do not have blood analysis for $\mathrm{Na}$ control, (c) who have pseudohyponatremia, and (d) $<18$ years old were excluded from the study.

Data from patients, including age (year), gender, total days of hospital stay, the lowest $\mathrm{Na}$ value measured after hyponatremia development $(\mathrm{mEq} / \mathrm{L})$, and treatments applied to the patients that may be related with hyponatremia before developing hyponatremia (hypotonic fluids, diuretics, mannitol, anticonvulsants, serotonin re-uptake inhibitors, renin-angiotensin receptor blockers, and surgical procedures), were collected, and for each patient, the sum of treatments that may cause hyponatremia was remarked under "Total Number of Factors." Finally, it was identified if mortality was observed in patients at the end of follow-up.

The threshold for hyponatremia is accepted as $135 \mathrm{mEq} / \mathrm{L}$, and patients are classified into three groups as mild (130$135 \mathrm{mEq} / \mathrm{L})$, moderate (I25-129 mEq/L), and severe (<125 $\mathrm{mEq} / \mathrm{L}$ ) according to the guidelines set by the "Hyponatremia Guideline Development Group” at the beginning of 2014.
Statistical analysis was made using SPSS 22.0 (SPSS Inc., Chicago, IL, USA). Along with definitive statistical methods (mean and median), the Mann-Whitney $U$ test was used for comparison of continuous parameters between two independent groups; the Kruskal-Wallis test was used for comparison between more than two independent groups. The Pearson chi-square test, Yates continuity correction test, or Fisher's exact test was used for comparison of qualitative data between the groups. The Shapiro-Wilk test was used for coherence of continuous variables to normal distribution. The correlation of continuous variables for parametric tests was evaluated by Pearson correlation coefficient, and Spearman correlation was used for nonparametric tests. Statistically significant numerical variables were subjected to linear logistic regression analysis.

Results were defined in $95 \%$ confidence interval. A p value $<0.05$ was considered as statistically significant.

\section{RESULTS}

Out of 133 hospital-related hyponatremia cases, 69 (51.9\%) were women, and 64 (48.1\%) were men. Their ages varied from 18 to 94 (median: 69.0; range: 76) years, and the length of hospital stay was between 2 and 150 (median: 21.0; range: 148) days.

The minimum $\mathrm{Na}$ value measured during hospitalization of the patients was $101 \mathrm{mEq} / \mathrm{L}$, and the maximum value was I3I (median: 125.0; range: 30) $\mathrm{mEq} / \mathrm{L}$. Of these cases, I I (8.3\%) were classified as mild, 62 (46.6\%) as moderate, and $60(45.1 \%)$ as severe hyponatremia.

Diuretics composed the largest part of medical treatments related to hyponatremia before the development of hyponatremia by $46.6 \%$. Hypotonic fluid administration followed by $22.6 \%$. Of the cases, $21.8 \%$ developed hyponatremia after surgical procedures. The use of other drugs (anticonvulsants, serotonin re-uptake inhibitors, and renin-angiotensin receptor blockers) composed $21 \%$ of the cases, and in $6 \%$ of the cases, mannitol was administered (Table I).

Table I. The relationship of demographic data and administered treatments with hyponatremia severity

\begin{tabular}{|c|c|c|c|c|c|}
\hline & Total $(n=133)$ & Mild $(n=I I)$ & Moderate $(n=62)$ & Severe $(n=60)$ & $\mathbf{p}$ \\
\hline & n (\%) & n (\%) & n (\%) & n (\%) & \\
\hline \multicolumn{6}{|l|}{ General features } \\
\hline Age, median (range) & $69.0(76)$ & $64.0(4 I)$ & $69.5(7 I)$ & $71.0(76)$ & ${ }^{\mathrm{a}} 0.290$ \\
\hline Length of hospital stay, median (range) & $21.0(148)$ & $16.0(58)$ & $23.0(148)$ & $23.5(75)$ & ${ }^{\mathrm{a}} 0.151$ \\
\hline$M: F$ & $64: 69$ & $2: 9$ & $28: 34$ & $34: 26$ & ${ }^{\mathrm{a}} 0.520$ \\
\hline \multicolumn{6}{|l|}{ Treatment before hyponatremia } \\
\hline Hypotonic fluids & $30(22.6)$ & $3(27.3)$ & II (I7.7) & $16(26.7)$ & '0 0.462 \\
\hline Diuretics & $62(46.6)$ & I (9.1) & $29(46.8)$ & $32(53.3)$ & ${ }^{\mathrm{b}} 0.026$ \\
\hline Mannitol & $6(4.5)$ & $0(0.0)$ & $4(6.5)$ & $2(3.3)$ & ${ }^{\circ} 0.811$ \\
\hline Other drugs & $21(15.8)$ & $0(0.0)$ & $10(16.1)$ & II (I8.3) & b0.307 \\
\hline Surgery & 29 (21.8) & $I(9.1)$ & I5 (24.2) & I3 (2I.7) & ${ }^{\circ} 0.535$ \\
\hline
\end{tabular}

a Mann-Whitney $U$ test. 'Pearson chi-square test. 'Fisher's exact test. ${ }^{*} p<0.05$; ${ }^{* *} p<0.00$ I. 
Table 2. The relationship of mortality with administered treatments

\begin{tabular}{|c|c|c|c|c|c|c|c|}
\hline & \multicolumn{2}{|c|}{$\begin{array}{c}\text { Total } \\
(n=\mid 33)\end{array}$} & \multicolumn{2}{|c|}{$\begin{array}{l}\text { Discharged alive } \\
\qquad(n=95)\end{array}$} & \multicolumn{2}{|c|}{$\begin{array}{l}\text { Death in hospital } \\
\qquad(n=38)\end{array}$} & \multirow[t]{2}{*}{$\mathbf{p}$} \\
\hline & $\mathbf{n}$ & $\%$ & $\mathbf{n}$ & $\%$ & $\mathbf{n}$ & $\%$ & \\
\hline Hypotonic fluids & 30 & 22.6 & 19 & 20.0 & II & 28.9 & ${ }^{\circ} 0.145$ \\
\hline Diuretics & 62 & 46.6 & 40 & 42.1 & 22 & 57.9 & ${ }^{b} 0.026$ \\
\hline Mannitol & 6 & 4.5 & 5 & 5.3 & I & 2.6 & ${ }^{\mathrm{a}} 0.674$ \\
\hline Other drugs & 21 & 15.8 & 14 & 14.7 & 7 & 18.4 & ${ }^{\circ} 0.792$ \\
\hline Surgery & 29 & 21.8 & 21 & 22.1 & 8 & 21.1 & bl. 000 \\
\hline
\end{tabular}

Figure I demonstrates that in $31 \%$ of the cases, none of these treatments were administered, and some of them were treated with more than one therapies. All hyponatremia-related treatments were administered to only I case.

Although a significant relationship between "Total Number of Factors" and "Mortality Rates" or "Hyponatremia Level" could not be identified (Table 2), when Pearson

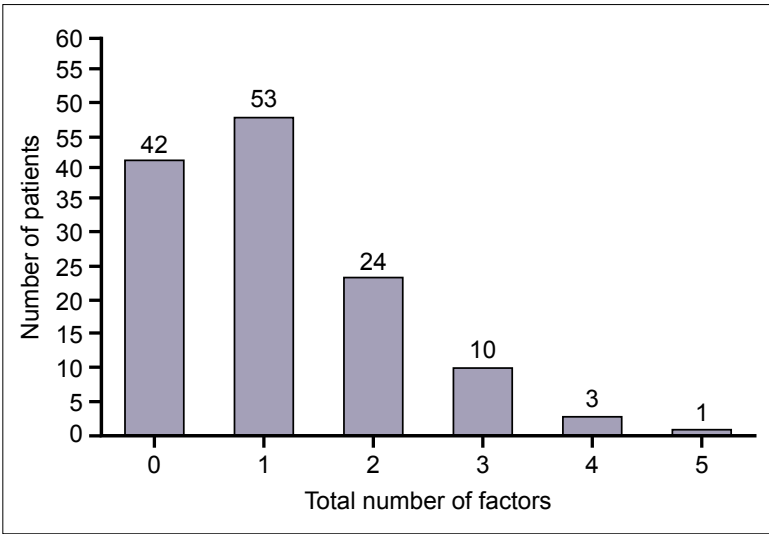

Figure 1. Total number of factors contributing to hyponatremia.

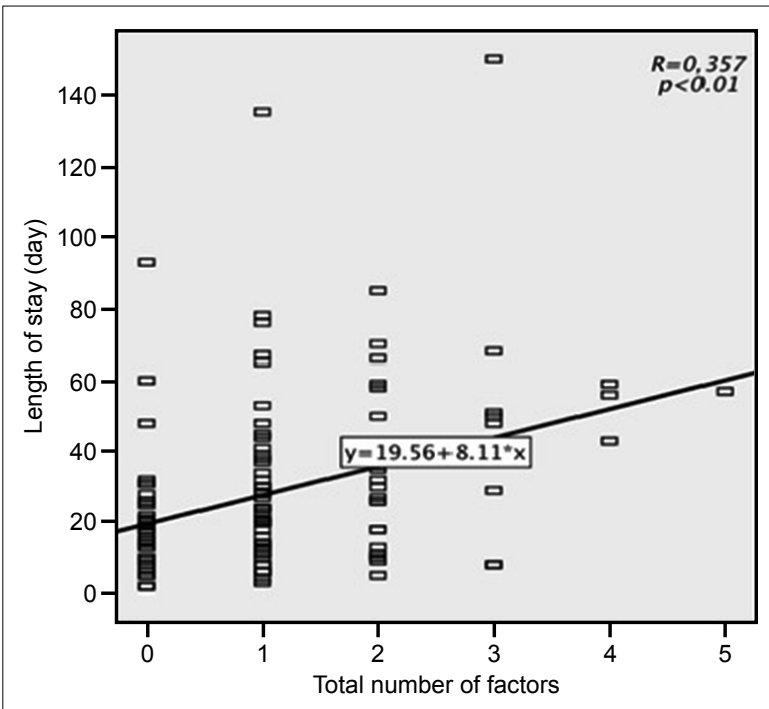

Figure 2. Linear model between total number of factors and length of hospital stay. correlation analysis was conducted, a linear and highly significant relationship between "Length of Stay" and "Total Number of Factors" was observed statistically $(R=0.357$, $\mathrm{p}<0.0 \mathrm{I}$ ) (Fig. 2).

If this correlation is analyzed by simple linear regression when any of the treatments that may cause hyponatremia (hypotonic fluids, mannitol, diuretics, other drugs, and surgery) was administered in addition to the current treatment, each factor seemed to prolong the length of hospital stay by $8.1 \pm I .853$ days (Fig. 2).

\section{DISCUSSION}

In this retrospective study, we aim to identify the risk factors of hospital-related hyponatremia and its relationship with mortality. According to the findings, we observed that certain treatments administered by physicians to inpatients for various reasons cause hyponatremia and prolong the length of hospital stay.

The causes of hospital-related hyponatremia were classified into five categories as hypotonic fluids, mannitol, diuretics, other drugs, and surgical procedures. How these treatments cause hyponatremia was discussed above. However, many factors other than these treatments may contribute to hospital-related hyponatremia. Anderson et al. in $1985^{[2]}$ and Gross et al. in 1987 ${ }^{[14]}$ demonstrated nonosmotic ADH release apart from volume status in hospitalized patients. Consequently, many patients are exposed to increased $\mathrm{ADH}$ levels during hospitalization because of miscellaneous reasons. Treatment approaches, such as hypotonic fluid administrations, also causes hyponatremia. ${ }^{[15]}$ Suggestion for the usage of hypotonic maintenance fluids in adult patients was proposed for the first time by Talbot et al. in 1953. ${ }^{16]}$ The authors constituted a theoretical model for the maximum and minimum tolerable water and $\mathrm{Na}$ concentrations in parenteral fluids based on the normal concentration and dilution ranges of the kidney. At that time, the use of $40 \mathrm{mEq} / \mathrm{L} \mathrm{NaCl}$ was suggested for maintenance fluids. Although they thought that an increase in $\mathrm{ADH}$ may have consequences on water retention, symptomatic hyponatremia may be a side effect. However, what they did not realize was how ADH excess was common among hospitalized patients. Undesirable consequences 
of hypotonic fluid administration were demonstrated especially in studies regarding the pediatric population. ${ }^{[6-10]}$ In the adult population, Hsiao-Min Chung et al. ${ }^{[5]}$ identified high levels of $A D H$ in postoperative patients in their prospective studies. In addition, they demonstrated that $94 \%$ of the patients are taking hypotonic fluids at the time of developing hyponatremia.

The present study is not appropriate to indicate the effect of the combination of factors on hyponatremia because of the absence of the control group. However, addition of each factor prolongs the length of hospital stay by approximately 8 days. Although this has no effect on mortality, it was significant to demonstrate patients who are open to new complications. In addition, this prolongation may increase the total costs of healthcare.

In conclusion, we suppose that the findings of the present study would help to identify patients who are at risk for hyponatremia, to define tailor made approaches for follow-ups and treatments, to shorten the length of hospital stay, and to prevent deaths from hospital-related hyponatremia.

\section{Conclusion}

As a conclusion of this retrospective study in which the effects of various treatments to 133 cases regarding hospital-related hyponatremia were searched, the following outcomes were inferred. We observed no significant relationship between treatments administered to inpatients before the development of hyponatremia and severity of hyponatremia or mortality level. However, it is determined that each and every treatment for hyponatremia prolonged the length of hospital stay.

According to these findings, we concluded that appropriate and individual approaches for treatments, especially avoiding the inappropriate use of hypotonic fluids and diuretics, are crucial to prevent hospital-related hyponatremia and its complications, to shorten the length of hospital stay, and to decrease the costs of healthcare.

Ethics Committee Approval

This was a retrospective study therefore no ethics commitee approval was taken.

Informed Consent

Retrospective study.

Peer-review

Internally peer-reviewed.

Authorship Contributions

Concept: Z.E.D., G.S.; Design: Z.E.D., G.S.; Supervision:
K.K., G.S.; Data collection \&/or processing: Z.E.D., M.T.; Analysis and/or interpretation: Z.E.D., Y.Ö.; Literature search: Z.E.D., S.T. ; Writing: Z.E.D.; Critical review: R.D.

Conflict of Interest

None declared.

\section{REFERENCES}

1. Upadhyay A, Jaber BL, Madias NE. Epidemiology of hyponatremia. Semin Nephrol 2009;29:227-38.

2. Anderson RJ, Chung HM, Kluge R, Schrier RW. Hyponatremia: a prospective analysis of its epidemiology and the pathogenetic role of vasopressin. Ann Intern Med 1985;102:164-8.

3. Asadollahi K, Beeching N, Gill G. Hyponatraemia as a risk factor for hospital mortality. QJM 2006;99:877-80.

4. Liamis G, Milionis $\mathrm{H} \&$ Elisaf M. A review of drug-induces hyponatraemia. American Journal of Kidney Diseases 200852 144-153.

5. Chung HM, Kluge R, Schrier RW, Anderson RJ. Postoperative hyponatremia. A prospective study. Arch Intern Med 1986;146:333-6.

6. Halberthal M, Halperin ML, Bohn D. Lesson of the week: Acute hyponatraemia in children admitted to hospital: retrospective analysis of factors contributing to its development and resolution. BMJ 2001;322:780-2.

7. Arieff AI, Ayus JC, Fraser CL. Hyponatraemia and death or permanent brain damage in healthy children. BMJ 1992;304:1218-22.

8. Armon K, Riordan A, Playfor S, Millman G, Khader A; Paediatric Research Society. Hyponatraemia and hypokalaemia during intravenous fluid administration. Arch Dis Child 2008;93:285-7.

9. Hoorn EJ, Geary D, Robb M, Halperin ML, Bohn D. Acute hyponatremia related to intravenous fluid administration in hospitalized children: an observational study. Pediatrics 2004;113:1279-84.

10. Moritz ML, Ayus JC. Preventing neurological complications from dysnatremias in children. Pediatr Nephrol 2005;20:1687-700.

11. Friedman E, Shadel M, Halkin H, Farfel Z. Thiazide-induced hyponatremia. Reproducibility by single dose rechallenge and an analysis of pathogenesis. Ann Intern Med 1989;110:24-30.

12. Spasovski G, Vanholder R, Allolio B, Annane D, Ball S, Bichet D, et al; Hyponatraemia Guideline Development Group. Clinical practice guideline on diagnosis and treatment of hyponatraemia. Nephrol Dial Transplant 2014;29 Suppl 2:11-39.

13. Aviram A, Pfau A, Czaczkes JW, Ullmann TD. Hyperosmolality with hyponatremia, caused by inappropriate administration of mannitol. Am J Med 1967;42:648-50.

14. Gross PA, Pehrisch H, Rascher W, Schömig A, Hackenthal E, Ritz E. Pathogenesis of clinical hyponatremia: observations of vasopressin and fluid intake in 100 hyponatremic medical patients. Eur J Clin Invest 1987;17:123-9.

15. Moritz ML, Ayus JC. Hospital-acquired hyponatremia-why are hypotonic parenteral fluids still being used? Nat Clin Pract Nephrol 2007;3:374-82.

16. Talbot NB, Crawford JD, Butler AM. Homeostatic limits to safe parenteral fluid therapy. N Engl J Med 1953;248:1100-8. 


\section{Hastane İlişkili Hiponatremi Gelişimi Öncesinde Yatan Hastalara Uygulanan Tedavilerin Etkileri}

Amaç: Hastane ilişkili hiponatremi anlamlı mortalite oranı olan ve yatan hastalarda sıklıkla karşılaşılan bir durumdur. Bu çalışmanın amacı hiponatremi gelişiminden önce yatan hastaların aldıkları tedavileri ve bu tedavilerle hiponatremi şiddeti, hastane yatış süreleri ve mortalite oranları arasındaki ilişkiyi ortaya koymaktır.

Gereç ve Yöntem: Bu çalışma 20I2-20I3 yılları arasında hastanemizde herhangi bir nedenle yatışı sırasında hiponatremi gelişen I 33 hastada geriye dönük olarak düzenlendi. Hastaların demografik özellikleri, hiponatremi sonrası sodyum verileri, hiponatremi gelişiminden önce uygulanmış tedaviler, hastane yatış süreleri ve mortalite oranları ve bunların birbirleriyle ilişkileri analiz edildi.

Bulgular: Hipoanatremi gelişimi öncesinde, hiponatremi ile ilişkili olailecek tedaviler arasında en büyük kısmı \%46.6 ile diüretikler oluşturmuştur. Hiponatremiye sebep olabilecek tedavilerden (hipotonik sıvılar, diüretikler, mannitol, diğer ilaçlar ve cerrahi) herhangi biri mevcut tedaviye ilave olarak uygulanırsa, her birinin tek başına hastane yatış süresini $8.1 \pm 1.853$ gün uzattığı görülmüştür.

Sonuç: Her ne kadar hipoanatremiye sebep olabilecek bu tedaviler ile hiponatremi şiddeti ya da mortalite arasında anlamlı bir ilişki gözlenmese de, hastane yatış sürelerindeki uzamanın, alınacak tedbirler sonrası hem yatış sırasında gelişebilecek komplikasyonların önlemesi hem de sağıı harcamalarının azaltılabilmesi açısından büyük önem taşıdığı düşünülmektedir. Ayrıca bu araştırmanın ileride yapılabilecek ileriye yönelik, olgu kontrollü çalışmalara ışık tutacağı düşünülmektedir.

Anahtar Sözcükler: Cerrahi; hastane ilişkili hiponatremi; hastane yatış süresi; mortalite; tıbbi tedaviler. 